Dubravka Sesar

FILOZOFSKI Fakultet SVeučILIšta U ZaGrebu

Zagreb, HRVATSKa

dsesar@ffzg.hr

Martina GrČević

FILOZOFSKI FAKULTET SVEuČILIŠTA U ZaGRebu

ZAGREB, HRVATSKa

mgrcevic@ffzg.hr

https://doi.org/10.17234/9789531755139.25

\title{
PAPCI I DRUGI MERONIMI ŽIVOTINJSKIH UDOVA U FRAZEMIMA HRVATSKOGA I POJEDINIH SLAVENSKIH JEZIKA
}

\begin{abstract}
Spoznaje današnjega europskoga čovjeka o svijetu jezično se očituju i u frazemima sa zoonimnom (animalnom) sastavnicom, u kojima se različita ljudska iskustva povezuju s ponašanjem pojedinih životinja, ponajprije onih koje najbolje poznajemo i koje možemo susresti u svojoj okolini. U ovome radu bavit ćemo se izabranim somatskim frazemima u kojima je osnovna sastavnica meronim, tj. krajnji dio (,,prsti“") životinjskoga ekstremiteta, odnosno holonima noga. Usporedba takvih frazema $u$ hrvatskom $\mathrm{s}$ istoznačnim ili bliskoznačnim frazemima u pojedinim slavenskim jezicima pokazat će određene kulturološke specifičnosti koje nisu nužno vezane uza životinje, a analiza njihova značenja i uporabe pokazat će i neke semantičke i pragmatičke pomake u iskazivanju tradicionalnoga i suvremenoga odnosa prema životinjama na frazeološkoj razini.
\end{abstract}

Ključne riječi: frazeologija, zoonimi, somatizmi, meronimi holonima noga, hrvatski, slavenski jezici

\section{Uvod}

Danas se u hrvatskim frazeološkim istraživanjima zamjećuju dva dominantna teorijska pristupa: onaj s duljom tradicijom razvile su mannheimska (J. Matešić) i zagrebačka, rusistička frazeološka škola (A. Menac, Ž. Fink Arsovski i dr.) ${ }^{1}$ koja frazemu pristupa sa strukturnoga i semantičkoga gledišta i definira ga kao semantički nedjeljivu cjelinu čije značenje ne čini zbroj značenja pojedinih sastavnica, dok se noviji pristup razvio iz konceptualnoga poimanja svijeta po kojemu u značenju frazema participiraju i njegove sastavnice, odnosno na mišljenju kognitivnih semantičara (koje zastupaju pretežno hrvatski anglisti, npr. M. Žic Fuchs) da je značenje frazema motivirano ljudskom konceptualizacijom svijeta koja se ostvaruje metaforom. Kao doživljaj i shvaćanje jedne

Mannheimska škola, koja se u međuvremenu ugasila, od zagrebačke se razlikovala ponajprije u poimanju granice frazema, $\mathrm{tj}$. $\mathrm{u}$ određivanju statusa minimalnoga frazema. 
pojave posredstvom druge metafora je, dakle, polazište ili izvor jezičnih izraza pa tako i frazema, koji su i po tradicionalnoj definiciji konvencionalni i nezamjenjivi. ${ }^{2}$ Naše istraživanje meronima životinjskih udova (nogu) kao sastavnica frazema u hrvatskom i većini drugih (ne svih) slavenskih jezika nužno se temelji na tradicionalnom pristupu, jer njega nameće sama potraga za formalnim i semantičkim ekvivalentima hrvatskoj natuknici papak u frazemima slavenskih jezika. ${ }^{3}$

Pretraživanje nacionalnoga korpusa i drugih hrvatskih internetskih izvora pokazuje da se leksem papak najčešće pojavljuje u prenesenom značenju, odnosno kao relativno nova metafora prilično širokoga značenja, ali uvijek s negativnom konotacijom. Budući da ta pojava nije frazeološka, njome se ne bismo trebali baviti, ali se, zbog mogućnosti da taj leksem s prenesenim značenjem postane sastavnica frazema, ni ona ne može zanemariti. U svome se istraživanju služimo semantičkim pojmovima holonim (cjelina) i meronim (dio cjeline), koji hijerarhijski određuju predmetno-značenjske odnose među kategorijski bliskim, a često i sinonimnim leksemima (usp. Opašić i Spicijarić Paškvan 2011: 62). Riječ je, naravno, o somatizmu koji pripada životinjskom (animalnom) svijetu i pojavljuje se u zoonimnoj frazeologiji.

\section{Papak u hrvatskoj i slavenskoj leksikologiji}

Etimologija imenice papak nije posve jasna; uz osnovno značenje (ungula, kopito) Skok navodi da je riječ hrvatska, srpska i dijelom slovenska: papak (Žumberak) = papek (Bela Krajina) = paponjak (Lika), ali u Resniku (Kosmet) čaponjak (papak u preživača i sitne stoke). Pretpostavlja da se sufiks -onjak pojavio križanjem s turskim babanak, a zbog č upućuje na usporedbu s čaporak (Skok 1972: 601).

Hrvatski rječnici i enciklopedije potvrđuju da papak i kopito imaju viši sisavci (Ungulata) koji se dijele na papkare ili parnoprstaše (Artiodactyla) i kopitare ili neparnoprstaše (Perissodactyla). Istu podjelu i isto nazivlje imaju i srpski i bosanski jezik. Iako slovenski bilježi starije, razgovorne nazive parkelj i parkljarji, u podjeli razlikuje dvije vrste kopitara: sodoprsti kopitarji (parkljarji) i lihoprsti kopitarji. Tako je i u ostalim slavenskim jezicima koje smo istražili (jedino ukrajinski nazivi imaju i slikovite sinonime): češki sudokopytníci i lichokopytníci, poljski parzystokopytne i nieparzystokopytne, slovački párnokopytníky i nepárnokopytníky, bjeloruski парнакапытныя і няпарнакапытныя, ruski парнокопытные і непарнокопытные ili непарнопалые, ukrajinski оленеподібні (jelenoliki) ili парнопалі, парнокопиті,

$2 \quad$ U posljednjih petnaestak godina pripadnici zagrebačke frazeološke škole u svojim su se radovima široko otvorili novim znanstvenim pristupima i konceptualnoj analizi. Govoreći o tematskoj organizaciji frazema (po uzoru na ruske frazeologe) zapravo su odavno anticipirali konceptualni pristup frazeologiji, kakav danas zagovaraju zapadni semantičari. Za razliku od naših kognitivnih semantičara zagrebačka frazeološka škola sustavno se i intenzivno bavi upravo hrvatskom frazeologijom i frazeografijom.

3 Prednost tradicionalnoga pristupa je i u tome što pomiruje različite teorijske pristupe frazeologiji u pojedinim slavenskim filologijama, a to se jasno očituje i u obradi frazema s izabranim sastavnicama u frazeološkim rječnicima slavenskih jezika. 
парнокопитні і конеподібні (konjoliki) ili непарнопалі, bugarski чифтокопитните i нечифтокопитните i makedonski парнокопитните і непарнокопитните. ${ }^{4}$

Iako se iz nazivlja može zaključiti da je u većini slavenskih jezika kopito istoznačnica za papak, definicije leksema kopito u jednojezičnim rječnicima pokazuju da je problem složeniji. U Anićevu rječniku (1998, 2003) definicijama papka i kopita dodani su različiti primjeri pa je papak, ,rožnata rasječena zaštitna tvorba koja pokriva vrhove prstiju nekih sisavaca (goveda, ovce, koze, svinje)“, a kopito je ,rožnata nerazdvojena tvorba noge u nekih životinja (konj, magarac, zebra)“. U većini jednojezičnih rječnika slavenskih jezika kopito se u primjerima povezuje i s kopitarima i s papkarima. Tako ruski rječnici - Kuznecov i TSR ${ }^{5}$ - uz definiciju kopita navode primjere kopita bika, konja, slona i nosoroga, iako je bik papkar. Ukrajinski VTSU daje definiciju bez primjera (,копито - роговое утворення в кінці ніг деяких ссавців“"), ali drugi naziv za kopitare - „копитні“" upućuje i na konjoliko i na jelenoliko stopalo (,кінь, олень...“). Makedonski TRM uz definiciju kopita navodi primjere koji se odnose i na konja i na jelena - „коньско копито, еленски копита, потковано копито“. Novi bugarski BTR kopito povezuje samo s konjem - „Подковавам копитата на кон“, dok ga stari RSB povezuje i s bivolom i divokozom. Slovački KSSJ i SSJ daju samo primjer s konjem „konské kopyto“, ali slovački nacionalni jezični korpus nudi i primjere s kravom, volom, bivolom itd. U češkom PSJČ definicija leksema kopyto najprije upućuje na kopitare neparnoprstaše s primjerom konja, ali unutar rječničkoga članka kopyto se odnosi i na papkare. U istom rječniku umanjenica kopýtko upućuje i na papkara ovcu. Poljski ISJP povezuje kopyto s konjem, kravom i antilopom - „,kopyto - to twarde zakończenie nogi u niektórych zwierząt, np. koni, krów i antylop“, iako su krave i antilope parnoprstaši, dok umanjenica kopytko upućuje na kozu. Valja napomenuti da kopito u češkom, poljskom, slovačkom i slovenskom, asocirajući na stopalo, ima i značenje postolarskoga kalupa.

Dvojezični rječnici slavenskih jezika uglavnom potvrđuju da hrvatski (srpski i bosanski) naziv papak u slavenskim jezicima - s iznimkom slovenskoga, gdje nalazimo istoznačnicu parkelj (KM) - znači kopito, npr. bugarski чифтно копито (SHB), ruski копьто (у непарнокопьтнызх) (D). U starijem makedonskom dvojezičnom rječniku za papak se ne navodi ekvivalent, nego se samo daje tumačenje: „дел од нога на копитцето кај некои животни“ (SHM). Inače se taj naziv u dvojezičnicima bolje precizira (kopito u ne/parnoprstaša), a obično se i proširuje stručnim nazivima ako takvi postoje - kao npr. u slovačkom: 1. kopyto, 2. ratica, paprčka (T). U značenju papak, tj. ungula kod parnoprstaša u češkom $\left(\mathrm{PN}^{6}\right)$ i slovačkom postoji i stručni naziv paznecht $(\mathrm{KSSJ})$.

$\overline{4} \quad$ Slična je podjela i u njemačkom jeziku: Paarhufer (paarzehige Huftiere, Paarzeher) i Unpaarhufer (Unpaarzeher).

$5 \quad$ Kratice rječnika navedene su uz naslove u popisu literature.

6 Profeta i Novosad (1999) za papak navode češki ekvivalent paznecht, ali ne i kopyto. Češki jednojezični rječnici, npr. oni u mrežnom projektu LEXIKO (http://lexiko.ujc.cas.cz), uopće ne navode paznecht, što upućuje na to da je uporaba riječi više ograničena na struku nego u slovačkom, gdje je paznecht potvrđen u KSSJ i SSJ. 
Slovački nazivi ratica, paprčka i paznecht rabe se ograničeno, više-manje među stručnjacima (npr. veterinarima), ali semantički nisu posve podudarni pa se paprčka i paznecht rabe i u značenju šapa ili pandža te u prenesenom značenju ljudske ruke ili nokta. Za papak poljski rječnici daju i naziv racica (ISJP), a ukrajinski pатиця (RUS), što su također stručni nazivi ograničene uporabe. Većina govornika spomenutih jezika ne poznaje te stručne pojmove.

U prenesenom značenju riječ papak nema formalnoga ekvivalenta u većini slavenskih jezika. Uz osnovno značenje Anićev rječnik iz 1998. navodi tri prenesena značenja: ,pren. iron. nožni prsti u čovjeka; žarg. cipela; deprec. razg. prostak, seljačina, primitivac, onaj koji se spušta s kamenjara ili dolazi iz zaostalih krajeva u gradove." Slična prenesena značenja daje i Anićev rječnik iz 2003., koji je precizniji u opisu trećega značenja: „razg. pejor. onaj koji se spušta s kamenjara ili dolazi iz zaostalih krajeva u gradove a. prostak, seljačina, primitivac b. bezvezant, niškoristi [on je papak, ništa on ne razumije]“. Sabljak u rječniku žargona iz 1981. navodi samo tri značenja: „,cipela; noga; čovjek na visokom položaju“, ali u najnovijem rječniku iz 2013. proširuje definiciju pa mu je papak: „cipela; noga; čovjek na visokom položaju; plašljivac, kukavica; beskičmenjak; papučar; prostak, seljačina, primitivac; žrtva prevare“, dok je augmentativ (pejorativ) papčina samo: „glupan, budala; beskičmenjak; plašljivac, kukavica; papučar“. Internetski izvori i nacionalni korpus otkrivaju da papak osim nožnih prstiju u čovjeka znači i stopalo i prste ruke, npr.

Masna domodrpatorska mažnjavanja silne love. Prohujalo sve pokraj mene. Da me barem i malo očešalo. Zalijepilo se za moje sirotinjske papke. Ovako, gdje si bio - nigdje. Što si radio - ništa (Vjesnik online, 07. 12. 2004., HJR).

„Rekoh li pravo, milostivi gospodine,“ okrenu se k Tahu, koji se je medju tim približio bio, te župnika gledao porugljivim okom. „Pravo, pravo! Maži si svoje papke svetim uljem, pa ćeš dobiti krila!“” odvrnu Tahi (August Šenoa (1885): Sabrane pripoviesti, HJR).

Starcu šikne krv u glavu. Opipa štap i odluči ne pobjeći, makar mu se smrzli svi papci (Sida Košutić (1940): S naših njiva. Bijele tišine, HJR).

Kad se značenje prenosi na ljudski karakter očito je u suvremenom hrvatskom žargonu rijetko kada riječ o prostaku i primitivcu, iako najnoviji Sabljakov rječnik (2013) potvrđuje i to. Najčešće je to osoba (obično muška) slaba karaktera, nesigurna, nesposobna, popustljiva, pokorna (obično ženi), naivna, plaha ili strašljiva, ukratko osoba koja po patrijarhalnim mjerilima nema osobine ,muškosti“, npr.

... na domak trajektu, ispred vaše stare ,četvorke“ u red uleti „glanc“ novi crni BMW. Tip je, jasno, pretekao cijelu kolonu i jednostavno zaključio da ste upravo vi taj ,papak“ ispred kojeg će bezbolno uletjeti (Večernji list, 10. 07. 2000).

Nikada nisam bio mangup ,na prvu loptu“, nikada nisam prvi provocirao i bahatio se, ali s druge strane, nisam bio ni papak (Slobodna Dalmacija, 06. 03. 2003). 
Na nagovor supruge i oca Šobot je otišao na razgovor pomirenja s Rajkom i Zecom, ali su ga ovi, tvrdi svjedokinja, ismijali rekavši mu ,da je papak“ (Vjesnik, 19. 02. 2002).

U nedjelju su IZBORI i nemoj biti papak, nego izađi na njih! (Slobodna Dalmacija, 22. 11. 2003).

Dapače, spominju se strpljenje i tolerancija, obilježja ,papka“ koji dopušta da ga žena vrti oko malog prsta. (Vjesnik, 02. 09. 2000)

Zar smo toliko nesigurni u sebe (po naški, papci) da ćemo dopustiti da nas drže u čekaonici u nedogled? Zar nisu neki narodi rekli da, zasad, ne žele u tu i takvu Europu? (Vjesnik, 13. 11. 2003).

... da je u trenutku kada su preuzeli pjesmu ona postala njihovo vlasništvo. Malo su se zabunili. Kao, mi smo papci, a oni sve znaju (Slobodna Dalmacija, 23. 02. 2001).

U značenju obilježene društvene kategorije (provincijalci, primitivci) papak i papci su najvjerojatnije preuzeti iz bosanskoga žargona, jer se i pojavljuju u takvom kontekstu:

U vrijeme moga studiranja u Sarajevu raju su činili mladi zgubidani, šibicari, propali studenti i sirotinja svake vrste, dok su papci bili svi ostali (Slobodna Dalmacija, 25. 01. 2001).

Onaj tko ne zna sitnim podvalama ,izvozati“ sugovornika može biti samo papak, pa bio on i akademik. Naravno, papci su bili svi došljaci iza sarajevskih brda, a mali broj se uspio ugurati u raju. Zato je Mesić mogao najjače uvrijediti Jelavića da ga je nazvao papkom (Slobodna Dalmacija, 25. 01. 2001).

U prenesenom značenju hrvatskome je najbliži papak u bosanskom ${ }^{7}$ i srpskom, ${ }^{8}$ parkelj u slovenskom ${ }^{9}$ te djelomično kopyto u češkom ${ }^{10}$ (u slovenskom, češkom i slovačkom kopito se odnosi i na ,vraga“"11).

$7 \quad$ U RBJ (2007) uz papak se navodi preneseno značenje 'neznalica', 'skorojević' te žargonizam 'dobre ženske noge'.

8 U RSJ (2011) navedeno je preneseno značenje 'prst u čovjeka' (Боли га папак), pri čemu se ne određuje je li to prst na nozi ili na ruci. U srpskom rječniku navodi se i frazem отегнути папке (пеј. умрети).

9 Kafol i Mirjanić (2006) za papak navode i preneseno značenje: 1. parkelj, 2. kmetavzar, neotesanec. U SSKJ (1979) navodi se parkelj u prenesenom značenju za ruku ili prste u čovjeka (Pokaži mi svoje parklje) te u značenju 'vrag' (črn parkelj) i 'krampus' - pratilac sv. Nikole.

10 U češkom kopyto ima i preneseno značenje 'budala', 'glupan', 'nespretnjaković' (SSJČ).

$11 \mathrm{Na}$ vraga asociraju metafore koje su se na razne načine frazeologizirale - u slovenskom hudičevo kopito (SSKJ), u češkom čertovo kopýtko (Č) i u slovačkom čertovo kopyto (KSSJ). 
Personifikacija papka ima svoju semantičku pozadinu u našem (hrvatskom) asocijativnom sustavu. Papak ponajprije asocira na ovcu ( $\mathrm{kad}$ je riječ o naivnosti i pokornosti „biti ovca“ i „,biti papak“ gotovo je istoznačno), a zatim na kozu, svinju i druge domaće papkare. Njih doživljavamo kao sitnu stoku, životinje kojima se ne može pripisati nikakvo dostojanstvo (kao npr. tipičnome kopitaru - konju). Iako je papak u suvremenom diskursu samo etiketa, metafora semantički bliska pojmovima kukavica, šonjo, luzer, papučar i sl., mogućnost da se ona frazeologizira pokazuju sklopovi s glagolom ispasti ${ }^{12}$ odnosno s glagolima u značenju 'pokazati se', 'ponašati se' u poredbenim konstrukcijama, npr.

Pokušajte zamisliti scenu: na poslu ste gadno zeznuli, pred kolegama vam je tip iz računovodstva dokazao da nemate pojma, ispali ste papak i neznalica (Večernji list, 14. 01. 2001).

Zbog strateške pogreške Edina Mujčina ja sam ispao papak (Slobodna Dalmacija, 18. 03. 2003).

Ako odemo vani i ne napravimo nikakvu frku, propast će nam gostovanje $\mathrm{i}$ ispast ćemo papci (Slobodna Dalmacija, 20. 07. 2002).

Ma, igrali su ko zadnji papci, nije ni čudo da su izgubili. Nisu imali nijednu pravu šansu, a nemreš zabit gol... (Večernji list, 14. 04. 2003).

Budući da u većini slavenskih jezika izvan spomenutoga kruga nismo našli potvrdu o sličnim prenesenim značenjima meronima papak, naša je pretpostavka da se u njima neće lako naći ni ekvivalenti hrvatskim frazemima s tom sastavnicom.

\section{Papak i slični meronimi u hrvatskoj i slavenskoj frazeologiji}

Istraživanja frazema s različitim meronimima životinjskih udova pokazuju zanimljive semantičke poveznice među slavenskim jezicima. Polazeći od hrvatskoga u analizi ćemo se detaljnije posvetiti značenjski bliskim frazemima sa somatski bliskim meronimom ili holonimom u pojedinim slavenskim jezicima. Navest ćemo i primjere slavenskih frazema za koje $\mathrm{u}$ hrvatskom ne postoji semantički ekvivalent $\mathrm{s}$ takvom sastavnicom, odnosno one koji u hrvatskom frazeološkom ekvivalentu nemaju traženi meronim ili pripadni holonim.

Uspoređeni (ovjereni) somatski frazemi mogu se na osnovi njihovih formalnih i semantičkih sličnosti i razlika razvrstati u četiri skupine (usp. Turk i Opašić 2008: 19) u kojima se očituje:

1. leksemna podudarnost frazemske sastavnice i pozadinske slike,

2. djelomična leksemna podudarnost frazemske sastavnice i sličnost pozadinske slike,

12 Pod natuknicom ispasti Anić (2003) u frazeme ubraja i primjer ,ispasti budala 1. osramotiti se ili učiniti što zbog čega se ostavlja dojam budale 2. doživjeti nezahvalnost, pokajati se zbog učinjene usluge, pokazane dobrote i sl.“” 
3. leksemna nepodudarnost frazemske sastavnice i sličnost pozadinske slike,

4. leksemna nepodudarnost frazemske sastavnice i različitost pozadinske slike.

Terminološke razlike koje nam otežavaju preciziranje značenja izabrane frazemske sastavnice naveli smo u 1. poglavlju. Budući da su papkar ili kopitar parnoprstaš (Artiodactyla) i kopitar neparnoprstaš (Perissodactyla) kohiponimi nadređenoga pojma kopitar(i) (Ungulata), papak i kopito su po istoj logici komeronimi holonima noga. Iako je osnovni leksički ekvivalent hrvatskome meronimu papak u većini slavenskih jezika kopito, pitanje je kakvu asocijaciju na taj pojam imaju govornici jezika u kojima nema leksema papak (u značenju: stopalo parnoprstaša, npr. ovce, koze, svinje, krave...). Osim konteksta, jasniji odgovor na to pitanje donekle mogu dati i frazemi s tim meronimom.

Po strogo terminološkom kriteriju najmanje bismo frazema s meronimom papak imali u 1. skupini, tim više što frazeološke usporedbe pokazuju da papak u hrvatskom i kopito u većini slavenskih jezika nisu potpuni semantički ekvivalenti, naime, kopito je semantički širi pojam i u drugim slavenskim jezicima može asocirati na stopalo konja, ali i na stopalo bilo kojega papkara. Na pitanje jesu li papak i kopito značenjski podudarni ili nepodudarni (ko)meronimi u pojedinim slavenskim frazemima ne može jednoznačno odgovoriti ni pozadinska slika. Da bismo ih svrstali u određenu skupinu, moramo se osloniti i na konceptualno poimanje životinjskoga svijeta, odnosno na specifična, kulturološki uvjetovana metaforička obilježja životinjskih meronima. Iz tih se razloga isti meronimi mogu pojaviti u različitim skupinama frazema, npr. meronim kopito pojavljuje se u svim skupinama, ali ne pripada uvijek semantički ekvivalentnim frazemima.

Značenjska povezanost meronima papak i kopito nužno navodi ne samo na frazeme sa sastavnicom kopito, nego i na one s meronimnim sastavnicama šapa, pandža i sl. Stoga pod meronimnom sastavnicom životinjskih udova (papak i dr.) podrazumijevamo i druge lekseme koji označavaju životinjske „prste“ i pripadaju holonimu $n o g a$, kao i one koji se u frazemima pojavljuju kao zamjenjive varijante ili kao sinonimi meronima „prsti“, a pripadaju hiperonimu životinja. U takvim frazemima noga može biti zamjenjiva varijanta meronima papak i kopito, ali ruka, šaka i sl. kao zamjenjive varijante meronima šapa, pandža i sl., unatoč semantičkoj bliskosti frazema, u pozadinskoj slici ipak nemaju životinjsko nego ljudsko tijelo. Ta nam razlika ne dopušta da meronime holonima noga i ruka svrstamo u istu skupinu. Isto načelo vrijedi i za istoznačne i bliskoznačne frazeme s meronimima prst i nokat, koji u pozadinskoj slici imaju ljudske meronime holonima ruka, a ponegdje i noga.

\subsection{Frazemi s podudarnim meronimom $\mathrm{i}$ istom pozadinskom slikom}

Najviše frazema pod natuknicom PAPAK sadrži Matešićev rječnik (M), gdje se 5 istoznačnih frazema (od ukupno 13) pojavljuje u formalno (leksički, morfološki i kvantitativno) manje ili više sličnim varijantama. Tako se cijeli korpus može sažeti na 8 frazema različitih značenja, od kojih je manji broj potvrđen i u drugim hrvatskim rječnicima: 


\section{imati (pružati) <svuda> svoje papke (M), tu su čiji papci (A) \\ izvući papke $(\mathrm{M})$ \\ ne ostaviti papka $(\mathrm{M})$ \\ otegnuti papke (M, HFR, HRR, MT, MR, MSK, A) - s varijantama: ispružiti \\ papke, odapeti papke (papcima), otegnuti papke (papcima) $(\mathrm{M})$ \\ tek što nije ohladio papke $(\mathrm{M})$ \\ pokazati (otkriti) papak (papke) $(\mathrm{M}, \mathrm{A})$ \\ skupiti papke (M, A), saviti (maknuti) papke (A) \\ zabosti (zakopati i sl.) papke u ledinu (M)}

Većina ovih frazema danas se u komunikaciji rabi vrlo rijetko. Češće se pojavljuju istoznačni frazemi s drugim sastavnicama i drugačijom pozadinskom slikom (v. 3.3. i 3.4.). Učestalost navedenih frazema u hrvatskom razgovornom jeziku teško je potvrditi, ali noviji hrvatski frazeološki rječnici s primjerima iz suvremenoga standardnoga jezika, kao i različiti hrvatski jezični korpusi, pokazuju da je ona vrlo niska ili nikakva. Mogući razlog tome je što korpus frazema u Matešićevu rječniku pripada i hrvatskome i srpskome jeziku, ${ }^{13}$ a sadrži i arhaične i regionalne frazeme koji nam nisu poznati i teško ih je potvrditi u suvremenim hrvatskim tekstovima. Budući da Matešić uz frazeme sa sastavnicom papak bilježi i sve njihove hrvatske istoznačnice i bliskoznačnice s drugim leksemnim sastavnicama i drugačijim pozadinskim slikama, takve ćemo frazeme uz gore navedene (sa sastavnicom papak) razvrstati u druge skupine i objasniti njihova značenja.

Jedini frazem iz gornjega popisa, koji pod natuknicom PAPAK bilježe svi hrvatski jednojezični i dvojezični frazeološki i opći rječnici, je frazem otegnuti papke u značenju 'umrijeti'. Za razliku od Matešića HFR ga navodi bez ijedne varijante, što je u skladu s učestalošću toga frazema u govoru i literaturi, jer je glagol otegnuti slikovitiji od varijantnoga ispružiti, a glagol odapeti funkcionira samostalno kao žargonizam sa značenjem 'umrijeti'.

Pozadinska slika frazema otegnuti papke ružna je slika smrti životinje, samoga kraja njezine agonije, koji se očituje prestankom trzaja, smirivanjem i konačnim opuštanjem udova (nogu). Svršenost je u frazemu izražena i glagolskim vidom, bez nesvršenoga vidskoga parnjaka. Frazem je preuzet iz ruralnoga svijeta, koji prema domaćim životinjama ima hladan, realističan odnos, a primijenjen na čovjeka uvijek ima negativnu, štoviše deprecijativnu konotaciju. Sa spoznajnoga gledišta frazem pripada konceptu smrti. Slična slika smrti s istom konotacijom pojavljuje se i u frazemima drugih (ne svih) slavenskih jezika.

Iako u slovenskom postoji potpuni leksički ekvivalent nazivu papak - parkelj, pl. parklji, s tom sastavnicom ne postoji frazem u značenju 'umrijeti'. Ne navodi ga ni Kerber u svome frazeološkom rječniku ni drugi slovenski rječnici kojima smo se

13 U primjerima koje potpisuje redakcija to je ponegdje teško razlučiti. Jedino uz frazem ne ostaviti papka u značenju 'ne ostaviti traga iza sebe' Matešić navodi primjer iz srpske književnosti, ali se istoznačni ili bliskoznačni frazem sa životinjskim meronimom ne pojavljuje ni u hrvatskim ni u drugim slavenskim jezicima. 
služili. ${ }^{14}$ Kao ekvivalent frazemu otegnuti papke potvrđen je samo frazem s ljudskim meronimom peta, koji zbog drugačije somatske sastavnice pripada 3 . skupini, te glagol iztegniti se (K) koji odgovara hrvatskom odapeti u značenju 'umrijeti'.

Najčešći leksički ekvivalent nazivu meronima papak u većini slavenskih jezika je, kao što smo vidjeli, kopito. Iako je taj meronim dvoznačan, on je unutar koncepta smrti jedina moguća sastavnica slavenskih frazema podudarna s hrvatskom sastavnicom papak. Pozadinske slike s tim sastavnicama preklapaju se potpuno ili gotovo potpuno, što pokazuju i sljedeći primjeri.

Slovački ekvivalenti frazemu otegnuti papke iskazuju se varijantama pod natuknicom KOPYTO: striasie kopytami, otrčí kopytá, už je hore kopytami (SSJ), odnosno striast' kopytami (krpcami), otrčit' kopytá (päty) (KSSJ, MSK). Glagolske sastavnice stresti, trznuti, izvrnuti stoje i uz dvije varijantne sastavnice - uz ljudski meronim peta i uz vrstu obuće (krpec), koje zbog drugačijih pozadinskih slika pripadaju 3. i 4. skupini frazema. ${ }^{15}$

Poljski frazemi pod natuknicom KOPYTO - wyciągnąć kopyta (CZP, BR, MP, PHR) i strzelić kopytami w kalendarz (CZP) - jednoznačni su ekvivalenti frazemu otegnuti papke. Drugi, u doslovnom značenju pogoditi kopitima kalendar, slikovito kazuje da je vrijeme života isteklo. Varijantni frazem wyciągnąć nogi (MP, BR, PHR) s holonimom noga pripada 3. skupini.

Uz brojne frazeme sa značenjem 'umrijeti' frazemu otegnuti papke i u ruskom odgovaraju frazemi откинуть (отбросить) копыта і протянуть ноги (HRR, RHSR, MT). Potonji frazem s holonimom noga pripada 3. skupini.

Frazem tek što nije ohladio papke (M) u značenju 'tek što nije umro (o čovjeku na samrti)', koji također pripada konceptu smrti (particip ohladio u govoru se najčešće zamjenjuje participom otegnuo), nije potvrđen u drugim hrvatskim rječnicima i teško mu je pronaći strukturni ekvivalent sličnoga značenja. Za značenjski bliske frazeme sa sastavnicom duša (npr. duša je na jeziku komu, HFR) postoje u slavenskim jezicima frazeološki ekvivalenti, ali nije pronađen ni jedan s nekim animalnim meronimom.

$14 \quad$ Uz frazem otegnuti papke u rječniku MR stoji slovenski ekvivalent stegniti parklje, što ne potvrđuje ni jedan slovenski rječnik (navodi se značenje 'posegnuti za nečim tuđim', odnosno 'hoteti si prisvojiti kaj'). Međutim, u korpusu Gigafida nalazi se i primjer sa značenjem 'umrijeti' iz revije Mladina: „In še nagradno vprašanje: koliko prašičev mora vsak teden stegniti parklje za pečenke, krvavice in pečenice..."

15 Našu analizu otežava činjenica da u različitim rječnicima (frazeološkim i općim), bez obzira na vrijeme njihova nastanka, nije ujednačeno određen položaj, odnosno učestalost meronimnih i alternativnih sastavnica pojedinih frazema. Npr. slovački rječnici ne preciziraju što je osnovna (primarna, najučestalija), a što varijantna sastavnica frazema otrčit’ kopytá (päty), a Smiešková (1989) ne navodi ni jedan frazem $\mathrm{s}$ tim sastavnicama. 


\subsection{Frazemi s djelomično podudarnim meronimima i sličnom pozadinskom slikom}

U ovu su skupinu svrstani frazemi sa somatskim sastavnicama koje u hrvatskom imaju značenje drugih meronima životinjskih udova.

Usporedba hrvatskih frazema sa sastavnicom papak, a posebno otegnuti papke, i slavenskih frazema s meronimom kopito otvara pitanje u kojim se hrvatskim frazemima pojavljuje kopito i koji su slavenski ekvivalenti takvih frazema.

Pod natuknicom KOPITO u hrvatskim se rječnicima pojavljuje frazem pod čijim kopitom (HFR, A), što znači 'pod čijom vlašću'. Frazem pripada konceptu moći, a vlast (moć, silu, snagu) u pozadinskoj slici simbolizira meronim snažnoga kopitara neparnoprstaša, ponajprije konja. Zanimljivo je da unatoč bogatoj frazeologiji sa sastavnicom kopito, posebno u slovačkom, češkom i slovenskom, u tim jezicima ne postoje frazemi s tom sastavnicom u okviru koncepta moći. Frazeološke ekvivalente nalazimo u ruskom i ukrajinskom, ali u oba s varijantnom sastavnicom peta pa oni zbog drugačije pozadinske slike (peta je meronim ljudske noge) pripadaju 3. skupini. Iz istoga razloga frazeološke istoznačnice sa sastavnicom jaram ili čizma pripadaju 4. skupini.

Osim frazemom pod čijim kopitom u hrvatskom se koncept moći iskazuje i frazemima biti u čijim šapama (M) i biti (naći se) u čijim pandžama (kandžama) ${ }^{16}$ (HFR). Pozadinske slike nisu iste, ali nisu ni bitno promijenjene, jer alternativne imeničke sastavnice frazema ne utječu na njihovo zajedničko semantičko obilježje 'biti u čijoj vlasti'. Mogući kolokat živjeti uz frazem pod čijim kopitom, koji se ne pojavljuje uz frazeme s meronimima šapa i pandža (kandža), također nema semantičkoga utjecaja na sam frazem.

Meronimnu sastavnicu šapa i pandža (kandža) ima većina frazema pomoću kojih se i u hrvatskom i u drugim u slavenskim jezicima iskazuje koncept moći. Pritom se šapa pojavljuje i kao meronim životinjske noge i kao holonim pojma pandža (kandža). U pozadinskoj slici može biti mačka (iz porodice zvijeri) koja na prednjim šapama ima pet prstiju (a na stražnjima četiri) s pandžama koje može uvući, može biti i jastreb ili orao (iz porodice ptica) s oštrim savijenim pandžama na svojim prstima, ali je vjerojatnije da u slavenskim jezicima moć simbolizira medvjed, velika i snažna zvijer koja pripada neparnoprstašima i ima šape s pet prstiju s pandžama koje se ne mogu uvući.

Razlike između semantički istih ili bliskih frazema kojima se iskazuje pozicija subjekta, nositelja moći ili vlasti, i onih kojima se iskazuje položaj objekta, potčinjenoga nečijoj moći ili vlasti, nisu samo strukturne naravi, nego se ponegdje temelje na različitim pozadinskim slikama koje se očituju u raznim varijantama.

16 U većini općih rječnika pandža i kandža navode se kao sinonimi, a noviji hrvatski frazeološki rječnici daju prednost pandži. Prema jezičnom osjećaju hrvatskih govornika pandža se češće doživljava kao meronim noge sisavaca, a kandža kao meronim ptičje noge. Takvu razliku navodi i Wikipedia: „Iako su službeno te riječi sinonimi, postoje nijanse u primjeni - "kandža" se češće koristi za ptice, a "pandža” za životinje (i ljude, pa odatle prezime Pandžić).“ 
Poziciju subjekta (nadređenoga) u hrvatskom iskazuju frazemi u značenju 'staviti koga, što pod svoju kontrolu (vlast), zagospodariti kim, čim' - staviti šapu na koga, na što ili staviti pod svoju šapu koga, što (HFR). Ruski im je ekvivalent наложить / налагать лапу (руку) на кого, на что (HRR), ukrajinski накласти / накладати лапу на кого (SUM), češki dostat někoho, něco do spárů (drápů, klepet, pazourů) (CZP), poljski dostawać kogoś, coś w swoje ręce (szpony) (CZP), a slovenski dobiti koga, kaj v svoje kremplje (K). U ruskom i ukrajinskom frazemu osnovni je meronim šapa (kao i u hrvatskom), u slovenskom pandža, češki ima najviše varijanti meronima pandža, a u poljskom je pandža varijanta osnovne sastavnice ruka.

Poziciju „moćnika“ iskazuju i istoznačni frazemi držati u < svojim> šapama koga, odnosno držati u <svojim> pandžama (kandžama) koga (HFR), kao i njegovi slavenski ekvivalenti s alternativnim meronimima šapa i pandža - ruski держать в лапах (когтях, руках, кулаке) кого, что і держать под <своей> лапой кого (HRR), ukrajinski тримати (держати) в кігтях кого, що (SUM), češki držet (mít) někoho v drápech (BR) i slovenski držati (imeti) $k$ oga, $\boldsymbol{k a j}$ v $<$ svojih $>$ krempljih (K). Poljski ekvivalent sa sastavnicom šaka pripada 3 . skupini frazema.

Poziciju objekta, podčinjenoga nečijoj moći ili vlasti, iskazuju frazemi s istim meronimima životinjske noge. Najviše bliskoznačnih frazema pojavljuje se u značenju 'pasti / padati pod čiju vlast' - dospjeti / dospijevati u čije šape (HRR), kojima potpuno (strukturno, slikovno i semantički) odgovara ruski frazem попасть / попадать (попасться / попадаться) в лапы (под лапу) кого (<к> кому) (HRR), a djelomično, s meronimom pandža, i ukrajinski потрапити / потрапляти в пазури кого ili опинитися / опинятися в пазурах кого, чого (SUM), češki dostat se někomu do drápů (BR), slovački dostat' sa niekomu, do niečich pazúrov (SSJ), poljski wpaść w czyjeś pazury (szpony) (BR, PHR) te slovenski frazem pasti v kremlje koga, česa (K). Slovački frazemi s holonimom ruka i meronimom šaka pripadaju 3. skupini.

Frazemima sa strukturom biti u čijim šapama (M) i biti (naći se) u čijim pandžama (kandžama) (HFR), u značenju 'biti pod čijom vlašću', 'biti u čijoj vlasti', u slovenskom odgovara frazem znajti se v krempljih koga, česa (K), u ruskom быть в когтях (лапах, руках, кулаке) у кого - s varijantnim meronimima šapa, ruka i šaka (HRR) te u ukrajinskom бути в кігтях кого (SUM). Frazemi bliskoga značenja sa sastavnicom jaram pripadaju 4. skupini.

Poseban izraz moći iskazuju slavenski frazemi s meronimom pandža u značenju 'spasiti, osloboditi koga, što od čije vlasti' i 'osloboditi se čije vlasti’ za koje u hrvatskim frazeološkim rječnicima nema zabilježenih ekvivalenata sa životinjskim meronimima. Semantički im odgovaraju hrvatski frazemi s ljudskim meronimom šaka, koji zbog drugačije pozadinske slike pripadaju 3. skupini.

\subsection{Frazemi s nepodudarnim somatskim sastavnicama i sličnim pozadinskim slikama}

U ovu su skupinu svrstani hrvatski frazemi s meronimima životinjske noge, koji u različitim slavenskim jezicima imaju frazeološke ekvivalente s drugačijim meronimnim sastavnicama. Zajednička im je karakteristika što u njima meronimi životinjske noge 
alterniraju i s meronimima ljudskih udova, stvarajući sličnu pozadinsku sliku. Slavenski su frazemi semantički ekvivalentni ponajprije hrvatskim frazemima s meronimima papak i kopito, a zatim šapa, pandža i dr., bez obzira na njihovu pripadnost određenom konceptu.

Frazem imati (pružati) < svuda> svoje papke (M) u značenju 'prikriveno se miješati u tuđe poslove, prikriveno utjecati na što' u hrvatskom najčešće zamjenjuju druga dva frazema: imati <svoje> prste $\boldsymbol{u}$ čemu $(\mathrm{HFR}, \mathrm{M})$ i pustiti / puštati < svoje> pipke (HFR, M, MSK), dakle frazem s ljudskim meronimom prst koji pripada holonimu ruka ili frazem sa životinjskim, ali „morskim“, meronimom pipak koji pripada holonimu krak (npr. hobotnice).

Ekvivalent hrvatskom frazemu imati < svoje> prste $\boldsymbol{u}$ čemu $(\mathrm{HFR}, \mathrm{M})$ sa sastavnicom prst pojavljuje se u većini slavenskih jezika, npr. u češkom mít $\boldsymbol{v}$ něčem prsty $\mathrm{i}$ strkat do něčeho prsty (CZP), u slovačkom mat' v niečom < svoje> prsty (KSSJ, S) i pchat' do niečoho prsty (SSJ, S), u poljskom maczać w czymś palce (CZP).

Frazemu otegnuti papke (v. 3.1.) u ovoj skupini odgovara slovenski ekvivalent s meronimom ljudske noge peta - iztegniti (stegniti) pete (K), kao i slovački - otrčit' päty (KSSJ, MSK), varijanta učestalijega frazema s meronimom kopito. Ljudski meronim peta u ovom frazemu pripada pozadinskoj slici koja asocira na smrt čovjeka.

Ukrajinski ekvivalent frazemu otegnuti papke u značenju 'umrijeti' vezuje se samo uz holonim noga - відкинути (простягти) ноги (MT, SUM). U pozadinskoj je slici smrt životinje, kao i u ruskom frazemu протянуть ноги (HRR, RHSR, MT) ${ }^{17}$ varijanti učestalijega откинуть (отбросить) копыта (HRR, RHSR).

Osim u značenju otegnuti papke, tj. 'umrijeti', poljski frazem s holonimom noga - wyciągnąc nogi (MP, BR, PHR) znači i protegnuti noge (HFR), tj. 'prošetati nakon duga sjedenja'. Ovaj je frazem primjer frazeoloških lažnih prijatelja.

Pod natuknicom PAPAK jedino Matešić navodi frazem zabosti (zakopati i sl.) papke u ledinu u značenju 'pobjeći, umaći, dati se u bijeg', ali pod natuknicom NOKAT (meronim prsta) daje i istoznačni frazem zabosti (zakopati, udariti) nokat (nokte) u ledinu te frazem zabosti nokat u ledinu u značenju 'poginuti'. $U$ većini hrvatskih frazeoloških rječnika značenje prvoga frazema iskazuje se drugačije, npr. frazemima s meronimom noge peta: podbrusiti pete, dati / davati petama vjetra (HFR). Semantički ekvivalenti u značenju 'pobjeći' s meronimom noga su im npr. u češkom vzít

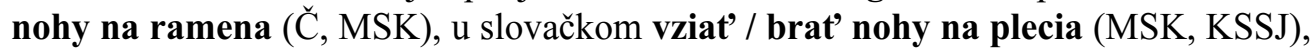
a u poljskom brać / wziąć nogy za pas, dać nogę (sa zamjenjivom sastavnicom drapaka) (CZP). Oni u značenju 'poginuti' s meronimom tijela glava pripadaju 4. skupini.

Hrvatskome frazemu pod čijim kopitom (HFR, A) semantički je najbliži ruski ekvivalent под пятой у кого (чьей) (HRR) i ukrajinski glagolski frazem koji pripada istome konceptu під п'ятою бути у кого, чиєю (SUM), oba s varijantnom sastavnicom peta (primarna je sastavnica jaram), koja je meronim ljudske noge i u pozadinskoj je slici moćan čovjek, osoba koja nekoga drži u svojoj vlasti.

17 Ruski frazem s holonimom noga, ali s drugim glagolima - вытянуть / вытягивать ноги (HRR, HRSR), frazeološki je ekvivalent hrvatskome protegnuti noge. 
Hrvatskim frazemima držati u < svojim> šapama koga i držati u < svojim> pandžama (kandžama) koga (HFR) semantički odgovara poljski ekvivalent trzymać (mieć) kogoś w garści (BR, PHR) te slovački mat' (držat') niekoho v hrsti (KSSJ, SSJ), u kojima se pojavljuje meronim ljudske ruke šaka.

U značenju 'pasti pod čiju vlast' hrvatskom frazemu dospjeti / dospijevati u čije šape (HRR) semantički odgovaraju slovački frazemi s ljudskim holonimom ruka padnút' do rúk niekoho i s meronimom šaka - dostat' sa pod päst' niekoho (SSJ).

Budući da u značenju 'spasiti, osloboditi koga, što od čije vlasti' i 'osloboditi se čije vlasti', u hrvatskim frazeološkim rječnicima nema zabilježenih ekvivalenata slavenskim frazemima s meronimom pandža, njima su semantički najbliži hrvatski frazemi $\mathrm{s}$ ljudskim meronimom šaka. Npr. češkim frazemima vyrvat něco, někoho z něčích drápů (spárů) i vyrvat se ze spárů (drápů, klepet, pazourů) někoho (BR, $\mathrm{CZP}$ ), slovačkome vytrhnút' niekoho, niečo (sa) z pazúrov niekoho, niečoho (SSJ) i poljskome wyrwać coś, kogoś $\boldsymbol{z}$ czyichś szponów (BR, CZP) odgovara hrvatski frazem izvući se (koga) iz čijih šaka (M), koji u pozadinskoj slici ima ljudskoga „moćnika“.

Frazemi u značenju 'upletati se u tuđe stvari' i sl. koji sadrže meronim životinjske noge (kao npr. u češkom) pripadaju 4. skupini, jer se u hrvatskom i u većini slavenskih jezika iskazuju značenjskim ekvivalentima s ljudskim meronimom nos, koji pripada holonimu glava.

\subsection{Frazemi s nepodudarnim sastavnicama i različitim pozadinskim slikama}

Ovoj skupini pripadaju hrvatski i slavenski frazemi u kojima meronimi životinjske noge alterniraju s drugim somatizmima, životinjskim ili ljudskim, kao i oni frazemi u čijem sastavu nema somatizama. Riječ je o frazeološkim ekvivalentima s različitim nosivim sastavnicama koje mijenjaju pozadinsku sliku, pri čemu frazemi zadržavaju najmanje jedno zajedničko semantičko obilježje.

Frazem izvući papke u značenju 'sretno se izvući iz neugodne, opasne situacije' ne potvrđuje ni jedan hrvatski frazeološki rječnik kojim smo se služili, a značenje mu se obično iskazuje samo glagolom izvući se ili frazemom izvući se / izvlačiti se (iskopati se i sl.) iz škripca (HFR). Somatsku sastavnicu nemaju ni drugi slavenski ekvivalenti, npr. slovački vybŕdnut' z kaše (KSSJ) ili ruski выйти / выходить из тупика, вырваться / вырываться из тисков (RFR).

Frazem pokazati (otkriti) papak (papke) u značenju 'otkriti se, odati se' bilježe samo dva hrvatska rječnika (M, A), dok istoznačni frazem otkriti / otkrivati <svoje> karte $\langle$ komu $>$ (HFR), u značenju 'pokazati / pokazivati svoje prave namjere, prestati / prestajati skrivati svoje namjere (mišljenje), očitovati se do kraja', nalazimo u svim rječnicima. I drugi slavenski jezici imaju frazeološke ekvivalente s istom sastavnicom, npr. češki odhalit (odkrýt) < své> karty (MSK), slovački odkryt' (ukázat') <svoje> karty (MSK), poljski odkryć / odkrywać < swoje> karty (MP), ruski открыть / открывать <свои> карты (RFR). Hrvatskome frazemu s meronimom papak djelomično su semantički ekvivalentni slavenski frazemi s meronimom pandža - češki mít (ukazovat, vytahovat) drápy (BR) i ukázat / ukazovat (vystrkovat) drápky (Č, CZP), slovački 
vystrčit' (ukázat') pazúry (KSSJ), poljski mieć (pokazać / pokazywać) pazurky (BR, CZP) i slovenski pokazati < svoje> kremplje (K), koji imaju širok raspon značenja. Osim 'pokazati / pokazivati svoju lošu narav, svoje zle namjere' znače i 'pokazati svoju drskost, bezobzirnost ili svoju moć' (K: 'pokazati svojo predrznost, hudobnost; pokazati moć, sposobnost'). Primjeri u rječnicima potvrđuju da je riječ o neočekivanom otkrivanju prave, loše ćudi ili pravih (skrivenih) namjera, suprotno prijašnjem suzdržanom ponašanju (npr. Č: „Byl to takový nenápadný člověk, ale sotva ho jmenovali vedoucím oddělení, začal ukazovat drápky."). Ovim frazemima semantički je najbliži hrvatski frazem pokazati / pokazivati <svoje> pravo lice (HFR) u značenju 'razotkriti / razotkrivati svoju pravu, neugodnu narav', koji s istom sastavnicom (lice), postoji i u drugim slavenskim jezicima. Zajedničko semantičko obilježje svih ovih frazema - 'odati se, razotkriti se' - pokazuje koliko su frazeološke razlike osjetljive i ovisne o kontekstu. ${ }^{18}$

U većini frazeoloških rječnika nije zabilježen ni frazem skupiti papke (M), saviti (maknuti) papke (A) u značenju 'povući se, skloniti se, pobjeći'. Takvo se značenje najčešće iskazuje frazemom podviti (podvući) rep (HFR, M, MSK i dr.) s karakterističnim životinjskim meronimom rep i s pozadinskom slikom pokunjena ili prestrašena psa koji se povlači. Identičnu pozadinsku sliku imaju i drugi slavenski jezici, npr. češki stáhnout (svěsit) ocas (Č, CZP), slovački stiahnut' chvost (KSSJ), poljski podwinąć (podkulić) ogon pod siebie (CZP), slovenski stisnuti (zviti) rep med noge (K), ruski поджать (подвернуть) хвост (RFR), ukrajinski підібгати хвоста (SUM) itd.

Frazemu otegnuti papke u slovačkom - uza spomenuti (u 1. skupini) ekvivalent s meronimom kopito (striast' kopytami, otrčit' kopytá) semantički odgovaraju i varijante otrčit' päty i striast' krpcami (KSSJ, MSK). Prvome je frazemu nosiva sastavnica meronim ljudske noge peta, a drugome neka vrsta opanka (krpec, g. krpca), lagane obuće (obično od lika), koja asocira na meronim ljudske noge - stopalo.

Češki semantički ekvivalenti frazemu otegnuti papke ne asociraju ni na kopita ni na životinje uopće, nego se najčešće pojavljuju pod natuknicom BAČKORA, tj. papuča, šlapa (u množini). U pozadinskoj slici frazema s tom sastavnicom - natáh-

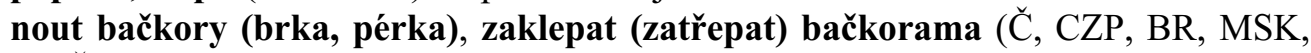
PSJČ) - je čovjek na smrtnoj postelji, a kućna obuća na njegovim nogama asocira na posljednji trzaj udova, odnosno stopala. Varijante s glagolskim sastavnicama otegnuti i zatresti pojavljuju se i pod natuknicama BRKO, PÉRKO - ptičje pero, perce, gdje se vjerojatno asocira na posljednji trzaj ptičjih krila.

Hrvatskome frazemu pod čijim kopitom (HFR, A) unutar koncepta moći odgovaraju frazemi: češki - být pod jařmem (jhem) někoho (CZP), poljski - być pod czyimś butem (jarzmem) (CZP), slovački - žit' pod cudzím jarmom (KSSJ), sloven-

$18 \quad$ Glagolske sastavnice pokazati / pokazivati navode (ili zavode) na frazeme sa somatskom sastavnicom zub (zube) u značenju 'oštro se usprotiviti, pobuniti se' (HFR) i rog (rogove) u značenju 'postati ratoboran, pobuniti se' (M), koji imaju drugačije semantičko obilježje (pobuniti se može i mirna, neratoborna osoba). Ipak, hrvatski frazem pokazati / pokazivati zube komu koji je naveden kao istoznačnica ruskome показать / показывать зубы (когти) кому s alternativnim sastavnicama zub i pandža (HRR, RHSR) upućuje i na djelomičnu semantičku podudarnost s frazemima u značenju 'odati se, razotkriti se'. 
ski - biti pod škornjem koga, česa (K), ruski - под игом у кого (чьим), под ярмом $\boldsymbol{y}$ кого (чьим) (HRR) i ukrajinski - бути під ярмом у кого ili у ярмі ходити te під чоботом чиӥм бути (SUM). Većina ih ima sastavnicu jaram, a u poljskom, slovenskom i ukrajinskom i čizma, te pripadaju posve drugačijoj pozadinskoj slici. Istoznačne frazeme sa sastavnicama jaram i čizma bilježe i hrvatski rječnici.

Za sljedeću podskupinu frazema polazište su nam bili slavenski jezici s meronimima životinjskih nogu, koji u hrvatskom nemaju ekvivalente s takvom sastavnicom. Navodimo ih samo kao primjere koji upotpunjuju naše frazeološke usporedbe i pokazuju da bi i naša analiza frazema s izabranim meronimnim sastavnicama bila drugačija kad bi polazišni bio neki drugi slavenski jezik.

Tako je npr. slovenskim frazemima pobrati kopita, pobrati šila in kopita $(K) u$ značenju 'pokupiti svoje stvari i otići' semantički blizak hrvatski pokupiti (skupiti, uzeti i sl.) svoje krpice. U pozadinskoj slici je osoba, vjerojatno uvrijeđena, koja raskida vezu i odlazi.

Dobar su primjer i češki, poljski, slovački i slovenski frazemi s meronimom kopito: češkome frazemu (být, dělat všechno) na jedno kopyto (Č, CZP), slovačkome (všetko je, robit' všetko) na jedno kopyto (KSSJ, SSJ), poljskome (wszystko jest, robić wszystko) na jedno kopyto (BR, CZP) i slovenskom (biti, iti) po enem (istem) kopitu (K) semantički odgovara hrvatski frazem (biti, raditi) <sve $>$ na isti (jedan) kalup (HFR, M). U pozadinskoj slici slavenskih frazema je kopito u značenju obućarskoga kalupa (!) koji ima formu stopala i podsjeća na kopito u somatskom značenju.

Isto su tako češkome frazemu $\mathbf{v}$ tom vězí čertovo kopýtko i njegovu slovačkom ekvivalentu v tom je čertovo kopyto u hrvatskom semantički najbliži frazemi <to> nije bez vraga u značenju ' $<$ to $>$ nije bez razloga, tu nešto nije u redu, iza toga se nešto krije' (HFR) i to nisu čista posla u značenju 'nešto je neispravno, protuzakonito, mutno' (HFR, MSK).

Nadalje, poljskome frazemu z kopyta (PHR) hrvatski je semantički ekvivalent kao iz topa (HFR) u značenju 'bez oklijevanja', kojima je zajedničko semantičko obilježje 'brzina, spremnost'.

Češkome frazemu roznést někoho na kopytech (Č, BR) i slovačkome rozniest' niečo, niekoho na kopytách (KSSJ) u značenju 'potpuno poraziti koga' semantički odgovara poljski rozbyć kogoś w pył sa sastavnicom prah (BR) te ruski разбить (разгромить) кого на́ голову sa sastavnicom glava i разбить (разгромить) в пух $\mathbf{и}<\mathbf{B}>$ прах кого sa sastavnicom prah (RFR), a značenjski im je u hrvatskom najbliži potući (poraziti i sl.) do nogu koga (HFR).

Češki frazemi strkat do všeho, do něčeho pazoury (pracky) i strkal pracky, kam neměl (CZP) u značenju 'upletati se u tuđe stvari, miješati se $u$ što, biti pretjerano znatiželjan' iskazuju se sličnim strukturama s ljudskim meronimom nos, koji pripada holonimu glava, i to u hrvatskom zabadati (gurati) $<$ svoj $>$ nos $<\boldsymbol{u}$ što $>$ (HFR), u poljskom pchać (wkładać, wsadzać, wtykać) nos $\boldsymbol{w}$ coś (CZP), u slovačkom strkat' (pchat') nos do niečoho (do všetkého, niekde) (KSSJ, SSJ, S), u ruskom совать <свой> нос во что і соваться <своим> носом во что (RFR). 
U značenju 'ukoriti koga, kazniti koga' češki frazem dát někomu přes pazoury (CZP) s meronimom pandža, poljski dać / dawać komuś po łapach (CZP) s meronimom šapa, slovački udriet' (klepnút') niekoho po prstoch (SSJ) s meronimom prst, ruski дать / давать по рукам кому (RHSR) s holonimom ruka i hrvatski dati komu po prstima (M) imaju različite pozadinske slike, ali ih sve povezuje holonim udovi. Analogni odnosi očituju se i u frazemima sa značenjem 'biti kažnjen' - češki dostat přes pazoury (CZP), poljski dostać / dostawać po łapach (CZP), slovački dostat' po prstoch (SSJ), ruski получить / получать по рукам (RFR) i hrvatski dobiti / dobivati po prstima (HFR).

Navedeni primjeri frazeoloških ekvivalenata s različitim somatskim i nesomatskim sastavnicama u različitim slavenskim jezicima pokazuju visoki stupanj semantičke podudarnosti. Isključimo li semantičke ekvivalente s nesomatskim sastavnicama, i u ovoj skupini frazema pozadinske slike rijetko su kada posve nepovezive i neusporedive.

\section{Zaključak}

Usporedba i analiza frazema sa sastavnicom papak i drugim meronimima životinjskih udova u hrvatskom i pojedinim slavenskim jezicima pokazala je ponajprije osnovne leksičke razlike između tih jezika. Nejasna razlika između papka i kopita te neprecizne definicije kopita u općim rječnicima ne mogu biti uzrok činjenici da se upravo ti meronimi (papak, odnosno kopito) ni u metaforičkom, personificiranom značenju ne pojavljuju u većini slavenskih jezika, a u frazeologiji uspoređenih jezika pojavljuju se rjeđe nego meronimi šapa i pandža. Vjerojatnije je uzrok u kulturološkim razlikama koje se očituju u različitim ljudskim iskustvima s ponašanjem životinja, ponajprije onih koje najbolje poznajemo i koje susrećemo u svojoj okolini, a ta su iskustva uvjetovana različitim odnosom prema domaćim životinjama koje imaju papke i kopita te onima koje imaju šape i pandže. Prosječan čovjek ne mora razlikovati kopitare parnoprstaše (papkare) od kopitara neparnoprstaša, ali ih seljak koji uz njih živi savršeno razlikuje. Njemu su krava, svinja, ovca, koza i konj ponajprije životinje od kojih živi, dok mu je mačka samo lovica miševa, a pas mu je čuvar kuće i stoke. Urbani čovjek drugačije doživljava životinjski svijet pa se, pogotovo u svom zauzimanju za prava životinja, umnogom razlikuje od ruralnih ljudi. Za njega su papci možda neki gastronomski pojam, a kopita ga podsjećaju na konja, možda trkaćega, dok za seoskoga čovjeka znače ponajprije brigu za zdravlje životinja. Odnos između čovjeka i životinje podrazumijeva i zahvalnost za njihovu korisnost i vjernost, a često znači i uzajamnu privrženost.

Frazeologija je svojevrsna memorija dugo stvaranih slikovitih i sažetih doživljaja svijeta i pokazuje ponajprije tradicionalan odnos prema životinjama, koji se zasniva na njihovoj vrijednosti i korisnosti za čovjeka. Stvarajući veliki broj svojih frazema na spoznajama o životinjama koje nas okružuju, mi jezično oblikujemo i svoj osjećaj moći, vlasti nad životinjama, a njihovu smrt (kao i smrt općenito) doživljavamo kao izraz krajnje nemoći i krajnje podređenosti višoj (ljudskoj) moći. Preslikavajući životinjsku moć i nemoć na svoj ljudski svijet, papke najčešće stavljamo u koncept smrti, a 
šape i pandže u koncept moći. Velika semantička, leksička pa i strukturna podudarnost među frazemima uspoređenih slavenskih jezika, kakvu pokazuje pojava meronima i holonima životinjskoga tijela u frazemima koji pripadaju konceptu smrti i konceptu moći (vlasti), ne postoji u frazemima s istim meronimima izvan tih dvaju koncepata. Ta su dva koncepta nužno povezana upravo kad je riječ o domaćim životinjama, odnosno o njihovim udovima.

Slavenski jezici u frazeologiji pokazuju širok raspon značenja i vrlo široku uporabu meronima životinjske noge, koja se zbog kulturoloških razlika i različitih asocijacija na pojedine meronime razlikuje od jezika do jezika. Kako smo u svojoj analizi hrvatski uspoređivali pretežno sa zapadnoslavenskim (uključujući i slovenski) i istočnoslavenskim jezicima (isključujući bjeloruski), možemo zaključiti da se veća frazeološka podudarnost očituje na sociokulturnoj nego na tradicionalnoj genetskolingvističkoj razini. Drugim riječima, frazemi s izabranim meronimnim sastavnicama u primarnoj uporabi (npr. šapa i pandža u odnosu na jaram) pokazuju jaču povezanost pojedinih kultura zapadnoga (Slavia latina) i istočnoga (Slavia orthodoxa) kruga, i to s vidljivim pokazateljima njihova dodira. Tako npr. ukrajinski frazemi pokazuju bliskost s ruskom i poljskom frazeološkom baštinom, dok je slovenski blizak zapadnoslavenskim jezicima i hrvatskom, a slovački ponajprije češkome i poljskome, ali i hrvatskome. Osim manje zastupljenosti frazema s meronimom papak - kopito od onih s meronimima šapa, pandža i sl. u svim slavenskim jezicima, analiza pokazuje i različitu zastupljenost frazema s alternativnim sastavnicama noga, šaka, prst i dr., koje označavaju i životinjske i ljudske udove. Takve su sastavnice češće u istočnoslavenskim (ruskom i ukrajinskom) nego u zapadnoslavenskim jezicima, među kojima je poljski svojevrsni dodirni jezik. Različiti frazeološki ekvivalenti bez somatskih sastavnica opća su pojava u svim slavenskim jezicima, povezana s međujezičnim dodirima i utjecajima (npr. između slovenskoga i češkoga).

Budući da nam je polazište za ovu analizu bio hrvatski jezik, odnosno hrvatska frazeologija, izostavili smo mnoge slavenske frazeme s meronimnim sastavnicama životinjskih udova, koji u hrvatskom nemaju ekvivalenta sa sličnom ili nekom drugom somatskom sastavnicom (primjere smo pokazali u poglavlju 3.4.) ili ga nemaju uopće (takav je npr. slovački frazem vyhodit' si z kopýtka u značenju 'dobro se zabaviti'). Ovakvi bi se frazemi mogli izdvojiti u posebnu skupinu, ali to bi značilo da unutar nje treba poći od pojedinih slavenskih jezika na koje bi se primijenili isti klasifikacijski kriteriji kao i na hrvatski. Ovom smo analizom nastojali iscrpiti cijeli ovjereni hrvatski frazeološki fond s izabranim sastavnicama i pokazati koliko se frazeološko bogatstvo s istim ili sličnim relativno malim brojem leksema krije i u drugim slavenskim jezicima. Primjeri koji zbog različitih pozadinskih slika pokazuju djelomičnu semantičku podudarnost, posebice oni sa somatskim sastavnicama $u$ skupinama 3.3. i 3.4., zahtijevaju podrobniju semantičku analizu i dobar su poticaj za temeljitije frazeološko istraživanje. 


\section{LITERATURA}

Bierich, Alexander. 1998. The semantic field „Death“ in Czech, Russian, Croatian and Serbian phraseology. U: Europhras '97: Phraseology and Paremiology (Liptovský Ján, 2.-5. 9. 1997). Ďurčo, Peter (red.). Bratislava: Akadémia PZ. 17-23.

Čermák, František. 1982. Idiomatika a frazeologie češtiny. Praha: Univerzita Karlova.

Fink 1999 = Финк, Желька. 1999. Русские и хорватские фразеологизмы со значением 'умереть'. U: Studia Russica XVII. Золтан, Андраш (red.). Будапешт: Будапештский университет им. Л. Этвеша, Факультет гуманитарных наук, Кафедра восточнославянской и балтийской филологии. 268-274.

Fink-Arsovski, Željka. 2002. Poredbena frazeologija: pogled izvana i iznutra. Zagreb: FF press. Hrnjak, Anita. 2001. O mogućnostima konceptualne i/ili tematske organizacije i obrade frazeologije. Filologija. 36-37: 189-200.

Kovačević, Barbara. 2012. Hrvatski frazemi od glave do pete. Zagreb: Institut za hrvatski jezik i jezikoslovlje.

Kulturni bestijarij. 2007. Marjanić, Suzana; Zaradija Kiš, Antonija (red.). Zagreb: Institut za etnologiju i folkloristiku - Hrvatska sveučilišna naklada.

Ladan, Tomislav. 2006. Etymologicon. Zagreb: Masmedia.

Menac, Antica. 2007. Hrvatska frazeologija. Zagreb: Knjigra.

Opašić, Maja; Spicijarić Paškvan, Nina. 2011. Holonim ruka i njegovi meronimi kao sastavnice hrvatskih i talijanskih frazema. Suvremena lingvistika. 21: 57-85.

Orłoś, Teresa Zofia. 2005. Studia z frazeologii czeskej i polskiej. Kraków: Wydawnictwo Uniwersytetu Jagiellońskiego.

Tafra, Branka. 2005. Od riječi do rječnika. Zagreb: Školska knjiga.

Turk, Marija; Opašić, Maja. 2008. Supostavna raščlamba frazema. Fluminensia. 1(20): 19-31.

Vidović Bolt, Ivana. 2011. Životinjski svijet u hrvatskoj i poljskoj frazeologiji I. Zagreb: Hrvatska sveučilišna naklada.

Visković, Nikola. 2009. Kulturna zoologija. Što je životinja čovjeku i što je čovjek životinji. Zagreb: Naklada Jesenski i Turk.

Žic Fuchs, Milena. 1992./1993. Konvencionalne i pjesničke metafore. Filologija. 20-21: 585593.

\section{RJEČNICI}

Anić, Vladimir. 1998. Rječnik hrvatskoga jezika. Zagreb: Liber.

Anić, Vladimir. 2003. Veliki rječnik hrvatskoga jezika. Zagreb: Novi Liber. [A]

Basaj, Mieczysław; Rytel, Danuta. 1981. Słownik frazeologiczny czesko-polski. Katowice: Uniwersytet Śląski. [BR]

Blgarski tlkoven rečnik 2003 = Български тълковен речник. 2004. Четвърто издание. София: Наука и изкуство. [BTR] 
Čedić, Ibrahim et al. 2007. Rječnik bosanskog jezika. Sarajevo: Institut za jezik. [RBJ]

Čermák, František et al. 1983-1994. Slovnik české frazeologie a idiomatiky I-IV. Praha: Academia. [Č]

Dautović, Matija. 2002. Hrvatsko-ruski rječnik. sv. 2. P-Ž. Zagreb: Školska knjiga. [D]

Fink Arsovski, Željka et al. 2006. Hrvatsko-slavenski rječnik poredbenih frazema. Zagreb: Knjigra. [HSRPF]

Igov 1959 = Игов, Ангел. 1959. Сърбохърватско-български речник. София: Държавно издателство Наука и изкуство. [SHB]

Inny słownik języka polskiego. 2000. Bańko, Mirosław (red.). t. I-II. Warszawa: Wydawnictwo Naukowe PWN. [ISJP]

Kafol, Igor; Mirjanić, Branka. 2006. Hrvaško-slovenski, slovensko-hrvaški slovar. Ljubljana: Modrijan. [KM]

Keber, Janez. 2011. Slovar slovenskih frazemov. Ljubljana: Založba ZRC, ZRC SAZU. [K]

Korać, Tatjana; Menac, Antica et al. 1979-1980. Русско хорватский или сербский фразеологический словарь / Rusko hrvatski ili srpski frazeološki rječnik. Menac, Antica (red.). sv. I-II. Zagreb: Školska knjiga. [RHSR]

Krátky slovník slovenského jazyka. 2003. Kačala, Ján; Pisárčiková, Mária (red.). Bratislava: Veda i Slovenská akadémia vied. [KSSJ]

Kuznecov 2002 = Кузнецов, Сергей Александрович. 2002. Большой толковый словарь русского языка. Санкт-Петербург: Норинт.

Matešić, Josip. 1982. Frazeološki rječnik hrvatskoga ili srpskog jezika. Zagreb: Školska knjiga. $[\mathrm{M}]$

Menac, Antica; Pintarić, Neda. 1986. Hrvatskosrpsko-poljski frazeološki rječnik. Zagreb: Zavod za lingvistiku Filozofskog fakulteta u Zagrebu. [MP]

Menac, Antica; Rojs, Jurij. 1992. Hrvatsko-slovenski frazeološki rječnik. Zagreb: Zavod za lingvistiku Filozofskog fakulteta u Zagrebu. [MR]

Menac, Antica; Trostinska, Raisa I. 1993. Hrvatsko-rusko-ukrajinski frazeološki rječnik. Zagreb: Zavod za lingvistiku Filozofskog fakulteta u Zagrebu. [MT]

Menac, Antica; Sesar, Dubravka; Kuchar, Renata. 1998. Hrvatsko-češko-slovački frazeološki rječnik s indeksom čeških i slovačkih frazema. Zagreb: Zavod za lingvistiku Filozofskog fakulteta u Zagrebu. [MSK]

Menac, Antica; Fink-Arsovski, Željka; Venturin, Radomir. 2003. Hrvatski frazeološki rječnik. Zagreb: Naklada Ljevak. [HFR]

Menac, Antica; Fink-Arsovski, Željka; Mironova Blažina, Irina; Venturin, Radomir. 2011. Hrvatsko-ruski frazeološki rječnik / Хорватско-русский фразеологический словарь. Zagreb: Knjigra. [HRR]

Moguš, Milan; Pintarić, Neda. 2002. Poljsko-hrvatski rječnik. Zagreb: Školska knjiga. [PHR]

Orłoś, Teresa Zofia. 2009. Wielki czesko-polski słownik frazeologiczny. Velký česko-polský frazeologický slovnik. Kraków: Wydawnictwo Uniwersytetu Jagiellońskiego. [CZP] 
Přiručni slovníkjazyka českého. 1935-1957. Praha: Česká akademie věd a umění. [PSJČ] Profeta, Dušanka; Novosad, Alen. 1999. Hrvatsko-češki rječnik. Zagreb: Informator. [PN] Rečnik na svremennija blgarski knižoven ezik 1955 = Речник на съвременния български книжовен език. Т. I. А-К. 1955. София: Българска академия на науките. [RSB]

Rečnik srpskoga jezika 2011 = Речник српскога језика. 2011. Нови Сад: Матица српска. [RSJ]

Russko-ukrajinskij slovar' 1961 = Русско-украинский словарь. 1961. Киев: Издательство Академии наук украинской CCP. [RUS]

Sabljak, Tomislav. 1981. Rječnik šatrovačkog govora. Zagreb: Globus.

Sabljak, Tomislav. 2013. Rječnik hrvatskog žargona. Zagreb: Profil.

Smiešková, Elena. 1989. Malý frazeologický slovnik. Bratislava: Slovenské pedagogické nakladatel'stvo. [S]

Skok, Petar. 1971-1974. Etimologijski rječnik hrvatskoga ili srpskoga jezika. sv. I-IV. Zagreb: Jugoslavenska akademija znanosti i umjetnosti.

Slovar slovenskega knjižnega jezika. Tretja knjiga Ne-Pre. 1979. Ljubljana: Slovenska akademija znanosti in umetnosti, Inštitut za slovenski jezik. [SSKJ]

Slovník slovenského jazyka. 1959-1968. Peciar, Štefan (red.). Bratislava: Slovenská akadémia vied. [SSJ]

Slovnik spisovného jazyka českého I-IV. 1960-1971. Havránek, Bohuslav (red.). Praha: Československá akademie věd. [SSJČ]

Slovnyk ukrajins'koji тоvy = Словник української мови I-XI. 1970-1980. Білодід, I. К. (red.). Київ: Наукова думка. [SUM]

Srpskohrvatsko-makedonski rečnik 1964 = Српскохрватско-македонски речник. 1964. Скопје і Обод, Цетиње. [SHM]

Takač, Ferdinand. 1999. Chorvátsko-slovenský slovník / Hrvatsko-slovački rječnik. Zagreb: Školska knjiga. [T]

Tolkoven rečnik na makedonskiot jazik 2005 = Толковен речник на македонскиот јазик. Том II 3-K. 2005. Скопје: Институт за македонски јазик Крсте Мисирков. [TRM]

Tolkovyj slovar' russkogo jazyka 1993 = Толковый словарь русского языка. 1993. Ожегов, Сергей И.; Шведова, Наталия Ю. Москва: АЗЬ. [TSR]

Velikij tlumačnij slovnik sučasnoji ukrajinskoji movi 2005 = Великий тлумачний словник сучасної украӥнської мови. 2005. Київ: ВТФ Перун. [VTSU]

\section{MREŽNI IZVORI}

Slovenský národný korpus: http://korpus.juls.savba.sk

Př́ruční slovník jazyka českého. 1935-1957. Praha: Česká akademie věd a umění: http://lexiko. ujc.cas.cz

Hrvatska jezična riznica $=$ HJR: http://riznica.ihjj.hr/index.hr.html

Hrvatski nacionalni korpus: http://www.hnk.ffzg.hr 


\section{SUMMARY}

\section{HOOVES AND OTHER MERONYMS OF ANIMAL LIMBS IN IDIOMS OF CROATIAN AND SOME OTHER SLAVIC LANGUAGES}

Linguistically the knowledge about the world of a modern European is reflected in idioms with zoonym (animal) components, in which various human experiences are connected with the behaviour of certain animals, primarily those we know best and those present in our environment. This paper examines selected somatic idioms in which the main component is a meronyme, i.e. the terminal part ("toes") of an animal extremity, i.e. of the holonym leg. The comparison of such idioms in Croatian with the idioms containing the same or similar meanings in certain Slavic languages presents certain cultural particularities that are not necessarily linked to animals, while the analysis of their meaning and usage shows some semantic and pragmatic shifts in expressing the traditional and contemporary relation to animals at the phraseological level.

Key words: phraseology, zoonyms, somatisms, meronyms of holonym “leg”, Croatian, Slavic languages 
